\title{
樹木管理に向けた中流域砂州の植生 遷移の動的予測モデルの開発 MODELING OF NUTRIENT DYNAMICS AND VEGETATION SUCCESSION IN MIDSTREAM SEDIMENT BARS OF A RIVER
}

\author{
浅枝 隆 ${ }^{1} \cdot$ Rabi'atul ABU BAKAR ${ }^{2} \cdot$ MD Harun RASHID $^{3}$ \\ Takashi ASAEDA, Rabi'atul ABU BAKAR, MD Harun RASHID
1 正会員 工博 埼玉大学教授 大学院理工学研究科 （†338-8570 埼玉県さいたま市桜区下大久保 255） 2 埼玉大学学生 大学院理工学研究科（干338-8570 埼玉県さいたま市桜区下大久保 255) \\ 3 博 (学) 埼玉大学助教 大学院理工学研究科 （テ338-8570 埼玉県さいたま市桜区下大久保 255)
}

\begin{abstract}
An individual based dynamic model describing Nitrogen cycles and vegetation growth and succession was developed. The model is composed of tree modules, where recruitment, self-thinning, growth, defoliation/decomposition processes were simulated, herbaceous plant modules, which provide the biomass given by the soil nitrogen content, soil particle size and shading effect by trees, and nitrogen budget modules, providing nitrogen budgets through the decomposition of herbs and tree leaves. The model was applied to the observed data at Aara and Kurobe rivers' sediment bars, showing the suitable agreement. Then, it was applied for the simulation of the 20-year succession, subjected to frequent floods to see the trend of vegetation biomass and nitrogen cycle.
\end{abstract}

Key words: vegetation, forestation modeling, nutrient dynamics, flood disturbance, sediment bar

\section{1. はじめに}

近年のレキ河原の安定は植生群落の発達を招き、 樹林化等の河川管理上の様々な弊害を引き起こして いる。しかし、元来、河岸には樹木群落は形成しや すく、環境上の観点からの問題は、樹木群落よりも、 むしろ、大量の草本群落が形成され、それらが微細 土砂を捕捉することに依って、より陸域化すること にある ${ }^{1)}$ 。河岸や砂州は、洪水による攪乱後は、多 くの植物が流失するために植物の量は減少し、また、 土壤表面には河川水で洗浄された貧栄養の土砂に覆 われる ${ }^{2,3)}$ 。そのため、その後の群落の発達は植生 の一次遷移の過程を辿る。こうした過程においては、 土壌の細粒化や栄養塩濃度の増加が植生のバイオマ スを増加させる ${ }^{4,5)}$ 。河岸や砂州の植生の管理を行 うためには、こうした過程を踏まえた評価方法が必 要であろう6)。ここでは、こうした過程に焦点をあ て、実用化の可能な定量的なモデル化を行うことを 目的としている。

\section{2. 砂州上の窒素循環}

Fig. 1 は砂州上の窒素循環の機構を表している。 砂州上においては、窒素分は、まず大気負荷および 洪水期の湛水の際に水中より供給される。地下水が 高い場所においては、植生によって地下水からも吸
収され、植物の枯死 - 分解の過程に依って砂州土壤 に供給される。樹木の場合には、葉に配分された窒 素分は、一部落葉時に枝に転流されるものの、多く は地上に落下した後、分解される。一方、幹や枝・ 根に配分されたものは長期間貯蔵される。草本類に 関しても、多年生草本の地下茎に配分されたものは 数年間貯蔵される。しかし、地上部の部位に配分さ れる大部分はその年の内に枯死し分解過程に入り、 窒素分は溶出する。

窒素固定細菌と共生する植物においては、大気中の 窒素ガスが固定され植物体に供給される。

ここでは、これまで行われた観測より得られる関 係を用いて、この過程のモデリングを試みる。

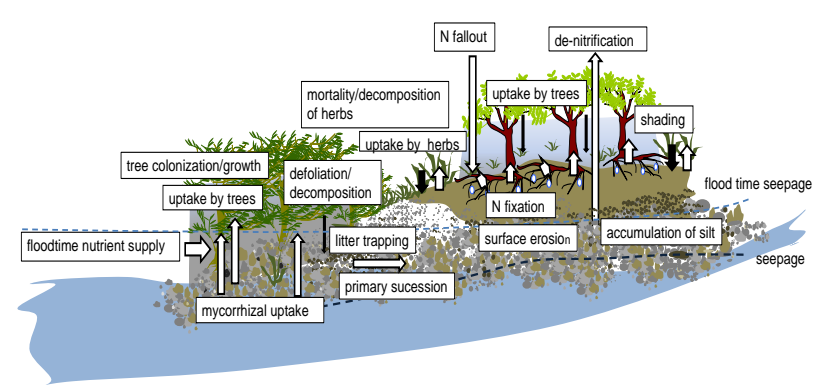

Fig. 1 Nitrogen budgets on the sediment bar 


\section{3. 樹木の定着と初期生長のモデル化}

河岸の樹木の多くは、種子が洪水に依って運ばれ、 それが砂州や河岸に定着することで種子散布が行わ れる。ところが生長においては土壌条件には大きく 左右されることはない。ここでは、典型的なものと して、窒素固定を行うもの、行わないものの代表種 として、カワヤナギ、ニセアカシアを対象とする。 まず、経験および荒川及び黒部川における観測 ${ }^{3)}$ り、これらの樹木の種子繁殖および初期生長特性を Table 1 のように定める。
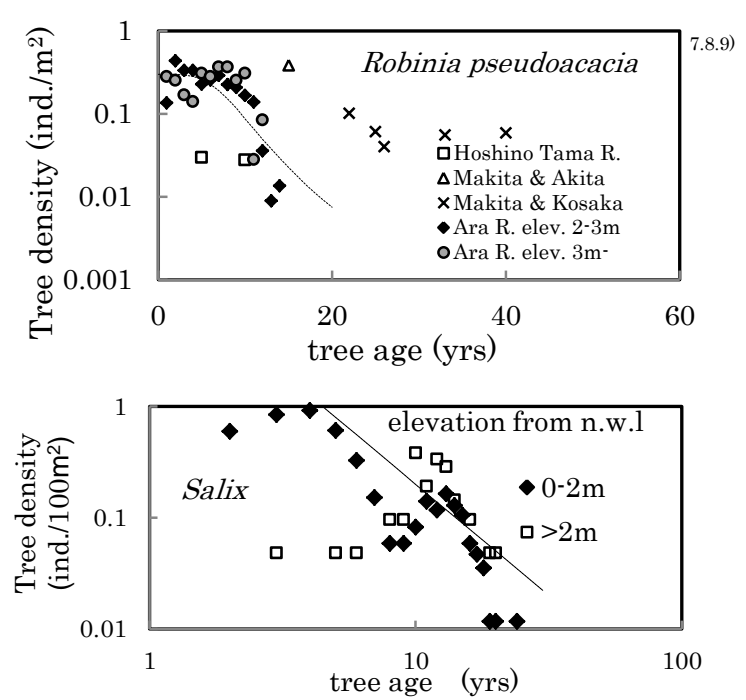

Fig. 2 Tree density vs. Tree age

Table 1 Encroachment condition of seedlings

\begin{tabular}{|c|c|c|}
\hline & \multicolumn{1}{|c|}{ Salix gilgiana } & Robinia pseudoacacia \\
\hline $\begin{array}{c}\text { Effective } \\
\text { floods }\end{array}$ & $\begin{array}{l}\text { Within 3 weeks after seed } \\
\text { dispersal }(\sim \text { May) }\end{array}$ & Aug - Sep \\
\hline $\begin{array}{c}\text { Germination } \\
\text { area }\end{array}$ & $\begin{array}{l}\text { On new accumulated sand } \\
\left(1 \mathrm{~mm}>\mathrm{D}_{50}>0.1 \mathrm{~mm}\right)\end{array}$ & $\begin{array}{c}\text { Within } 0.5 \mathrm{~m} \text { from } \mathrm{n} . \mathrm{w} .1 \text { at } \\
\text { floods (mostly fine soil area) }\end{array}$ \\
\hline $\begin{array}{c}\text { Seedling } \\
\text { density }\left(/ \mathrm{m}^{2}\right)\end{array}$ & $39 \mathrm{ind} / \mathrm{m}^{2}$ & $0.3 \mathrm{ind} / \mathrm{m}^{2}$ \\
\hline $\begin{array}{c}\text { Self-thinning } \\
\left.\text { (ind } / \mathrm{m}^{2}\right)\end{array}$ & $20 / A G E^{2}$ & $0.3 \frac{8^{4}}{8^{4}+A G E^{4}}$ \\
\hline
\end{tabular}

\section{4. 樹木個体の生長モデル}

樹木個体の形態は、多くの場合、直径のアロメト リー式で与えられる ${ }^{10)}$ 。ここではさらに、直径と樹 齢との関係を利用して、樹木形態、バイオマスを樹 齢との関係で表すことにする。

年間の生長量は、幹/枝および根のバイオマス $(A G B$ と $B G B)$ は Asaeda et al. ${ }^{11)}$ による樹齢 $(A G E)$ を 用いたアロメトリー式

$$
\begin{gathered}
A G B_{\text {sal }}=0.0195 D K H_{\text {sal }}{ }^{4.45} \\
B G B_{\text {sal }}=0.0111 D K H_{\text {sal }}{ }^{3.51} \\
(r=0.98, P<0.91 ; 5 \mathrm{~cm}<D K H<27 \mathrm{~cm}) \\
A G B_{\text {rob }}=0.00141 D K H_{\text {rob }}{ }^{4.63} \\
B G B_{\text {rob }}=0.00456 D K H_{\text {rob }}{ }^{3.65} \\
(r=0.97, P<0.01 ; 1 \mathrm{~cm}<D K H<13 \mathrm{~cm})
\end{gathered}
$$

より以下のように求まる。 $D K H$ は膝高直径で $\mathrm{sal}$ 、 $r o b$ の添字はそれぞれ、ヤナギ、ニセアカシアであ る。

$$
\begin{aligned}
& A G B_{\text {sal }}=0.0867 A G E_{\text {sal }}{ }^{3.45} \\
& A G B_{\text {rob }}=0.00655 A G E_{\text {rob. }} 3.63 \\
& B G B_{\text {sal }}=0.0391 A G E_{\text {sal }}^{2.51} \\
& B G B_{\text {rob }}=0.0167 A G E_{\text {rob }} 2.65
\end{aligned}
$$

また、落葉直前の葉のバイオマス LB $(\mathrm{kg})$ も以下 のように与えられる。

$$
\begin{aligned}
L B_{\text {sal }} & =0.089 A G E_{\text {sal }}^{1.05} \\
L B_{\text {rob }} & =0.023 A G E_{\text {rob }}^{1.0}
\end{aligned}
$$

さらに、樹冠幅 $(C W)$ についは、

$$
\begin{aligned}
& C W_{\text {sal }}=32.9 D K H_{\text {sal }}^{1.14} \\
& C W_{\text {rob }}=69.0 D K H_{\text {rob }}^{0.775}
\end{aligned}
$$

で与えられる。

\section{5. 草本類バイオマスのモデリング}

砂州上においては日射は豊富なために、樹木で陰 になる場合を除き、草本類の生長は日射量に依存す る。一方、砂州土壌は貧栄養な為に、栄養塩濃度に 依る律速の程度は高い。また、土壌粒径が粗いこと は、土袞水分による律速の条件も高い。

そのため、草本類のバイオマスは、土壤中の窒素 濃度、土壌粒径、樹木による陰によって定まるもの とする。

Fig. 3 は、様々な河川の砂州で採取された草本類 の $1 \mathrm{~m}^{2}$ あたりのバイオマス(乾燥重量) と土壌窒素濃 度との関係を、ヨシやオギ等の大型イネ科植物と他 の植物に分けて示したものである。ここで、黒印は、 他の条件で生長が律速されていた場合、白印は、律 速を受けていない場合の結果である。多少のバラつ きはあるものの、概ね、土猿中の $\mathrm{TN}(\% \mathrm{w} / \mathrm{w})$ に対し、

$$
A G B=A G B_{\max }\left[\mathrm{TN}^{2.5} /\left(\mathrm{TN}^{2.5}+0.04^{2.5}\right)\right]
$$

で表される。ただし、 $A G B_{\max }$ は、大型イネ科植物群 落で $1500 \mathrm{gDW} / \mathrm{m}^{2}$ 、他の群落で $400 \mathrm{gDW} / \mathrm{m}^{2}$ である。

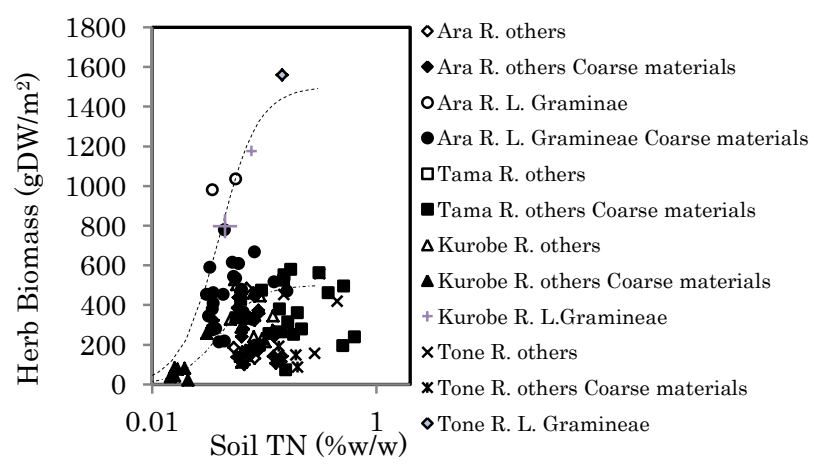

Fig. 3 Herb biomass vs. soil TN. Dashed line indicates (7)

次に、Fig. 4に、草本類バイオマスと土壌粒径と の関係を示す。ここでも、土壌窒素濃度に対する結 
果と同様に、黒印は、他の条件で生長が律速されて いた場合、白印は、律速を受けていない場合の結果 である。多少のバラつきはあるものの経験的に

$$
\begin{gathered}
A G B_{g}=A G B_{\max }\left[2.5^{3} /\left\{2.5^{3}+\left(2+\log \mathrm{D}_{50}\right)^{3}\right\}\right] \\
A G B_{o}=A G B_{\max }\left[3^{2} /\left\{3^{2}+\left(2+\log \mathrm{D}_{50}\right)^{2}\right\}\right]
\end{gathered}
$$

のように表される。ただし、AGBg、AGBo はそれ ぞれ、大型イネ科植物、他の植物群落を表す。また、 $\mathrm{D}_{50}$ は平均粒径である。

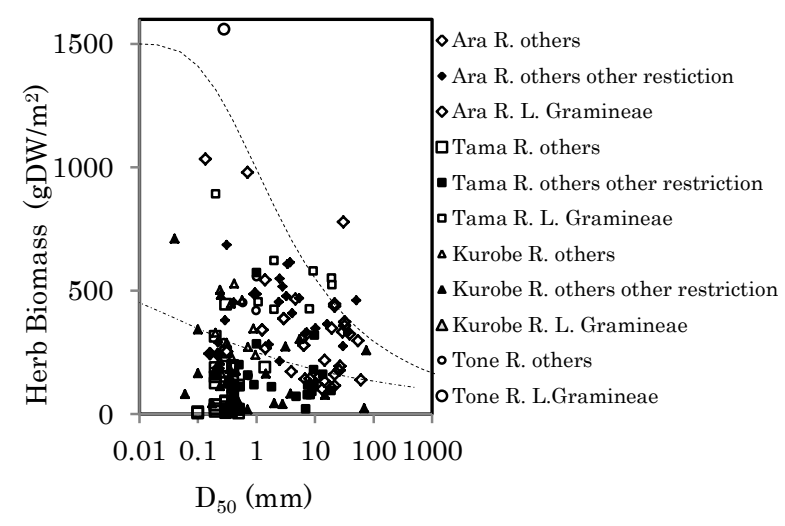

Fig. 4 Herb biomass vs. $D_{50}$. Dashed Iine indicates (8)

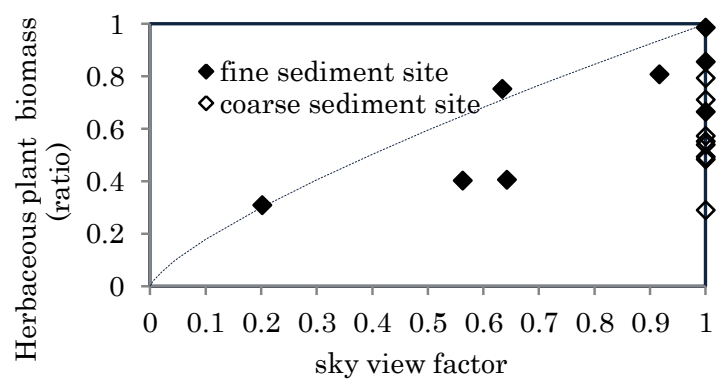

Fig. 5 Sky view factor vs. herbaceous plant biomass/nearby biomass. Dashed I ine indicates (9)

Fig. 5は、樹木の陰よる影響である。横軸に天空 率をとり、草本類のバイオマスと近傍の陰の影響を 受けていないバイオマスの比を表している。ここで、 白印は、土畩粒径が大きい場所のものであり、土壌 粒径によって生長が律速されているものである。

この図より、概ね、樹木の陰によってバイオマス が減少する割合を示す係数 $S_{H}$ は、以下のように表 される。

$$
S_{H}=1-2\left(\frac{\text { Leaf }}{3.14\left(\frac{C W}{2}\right)^{2}}\right)
$$

以上の関係を用い、草本類の年間最大バイオマス 量をこれらの積で表すことにする。なお、洪水攪乱 後、数年は群落の形成途上にあたり、バイオマスも
十分な地下茎が形成するまで徐々に増加する。ヨシ の結果を参考に、以下の関係を用い、遷移過程を表 すものとする。

\section{6. 分解過程の表現}

分解速度は、現存する重量に比例することから、 落葉後、時間 $t$ の間に分解速された量 $B_{D}$ は、地面 に落下した葉のバイオマス Leaf $(1-a)$ に対し、最も 単純な表現形式として、

$$
B_{D}(t)=L e a f(1-a)(1-\exp (-k t))
$$

で表される。分解速度を示す係数 $k$ は植物の種類、 地表面の状態によって異なるが、 $k=0.0024(/ y r)$ 程 度である(Zhang et al. $\left.{ }^{12}\right)$ 。 $a$ は落葉の際の転流の割合 を示し、平均 0.3 程度である。

草本類の場合には、多年生草本類の場合、Leaf の 代わりに地上部バイオマス $A G B_{H}$ を用いればよい。 地下茎に転流される割合 $a$ は、この場合、土壤粒子 の粒径、土壤水分や土壤栄養塩の条件に左右される が、草本類全体で扱う場合には $a=0.3$ 程度でよい ${ }^{13)}$

\section{7. 植物体内の窒素濃度}

植物体内の窒素濃度は、葉で高く、根で低い。こ れまでの観測結果より概ね Table 2 ようにまとめら れる。

Table 2 Nitrogen contents of plant tissues (\%w/w)

\begin{tabular}{|c|c|c|c|}
\hline & leaves & stems & roots \\
\hline Salix gilgiana & 2.0 & 0.4 & 0.9 \\
\hline $\begin{array}{c}\text { Robinia } \\
\text { pseudoacacia }\end{array}$ & 3.0 & 0.6 & 1.4 \\
\hline Graminae & 3.0 & 0.6 & 1.0 \\
\hline Others & 3.0 & 1.0 & 1.0 \\
\hline
\end{tabular}

分解時における窒素の溶出は、必ずしもバイオマ スの減少割合と同じになるわけではないが、ここで は、バイオマス減少分にこの割合を掛けた量の窒素 分が溶出されると仮定する。

\section{8．窒素固定量の見積もり}

窒素固定には大量のエネルギーを消費するため、 土袞中の窒素濃度が高い間は、窒素固定は行われな い。

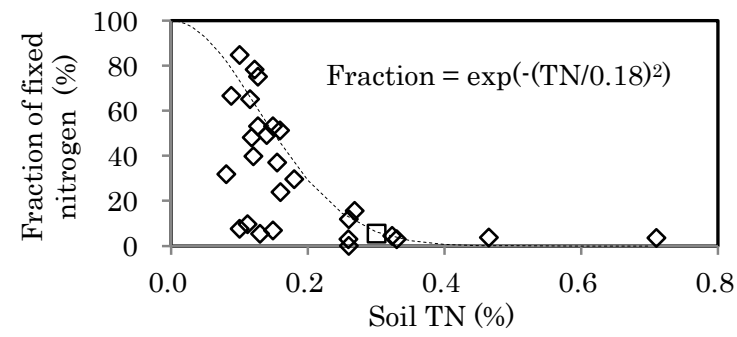

Fig. 6 fraction of fixed nitrogen vs. soil TN 
Fig. 6 は、多摩川のクズで測定された、植物体中 の全窒素濃度に対する窒素固定の割合を、土㙵窒素 濃度に対して示したものである（未発表）。

図より、植物体中の窒素分の内、縦軸で示される割 合が、窒素固定に依って大気から供給されたものと して考えることが可能である。

\section{9. シミュレーション過程}

以上のような結果を用いて、砂州土壤の栄養塩濃 度の変化、それに伴う草本類バイオマスの予測が可 能になる。Fig. 7 は、計算の過程の概略図である。

モデルは、大きく樹木群落のモジュールと草本群 落モジュール、さらに、それらが枯死・分解するこ とで生ずる窒素循環モジュールからなる。植生モデ ルの開発を目的としているために、現段階では、砂 州の変形や植物の流失に関しては、経験式 ${ }^{11)}$ を用 いるが、二次元河床変動モデル等に接続することで、 砂州形状の変化、植生の流出率の計算結果等を含め ることは可能である。

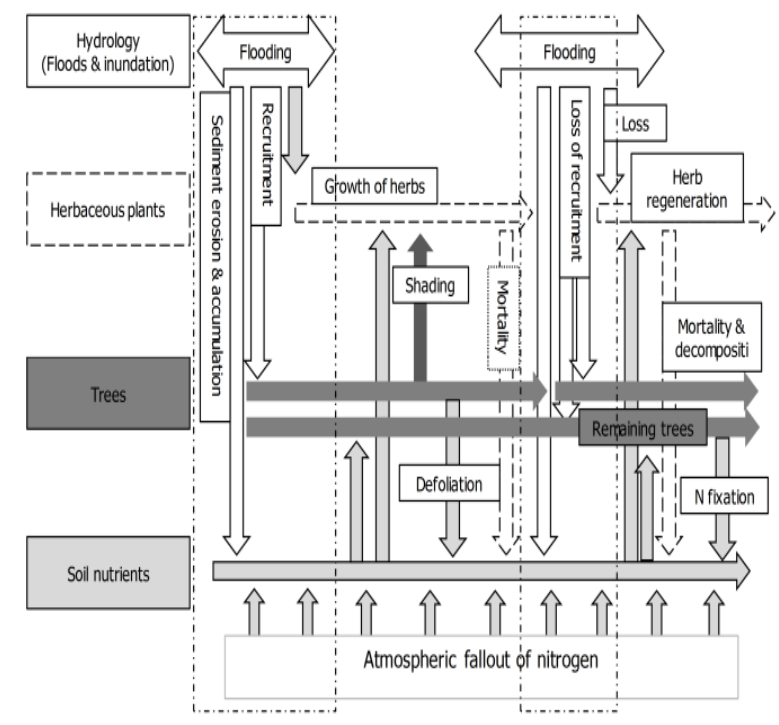

Fig. 7 Schematic diagram of the model

以下に計算の手順を示す。

\section{（1）樹木群落のシミュレーション}

・樹木の侵入過程 洪水時の水位予測 (記録)によっ て、砂州上で洪水時に冠水する標高を算出し、砂 州上の土袞粒径の分布、洪水の時期、冠水高より、 侵入する樹種を定める。また、洪水の時期や水位 等から求められる、それぞれの場所に侵入する樹 種に対し、初期の樹木密度を求める。

・樹木個体群の生長 それぞれの樹木種の個体生長 モデルにより、根および幹、枝等の年間のバイオ マス増加量を、樹齢ごとに算出する。同時に、そ
れぞれの樹木種の自己間引き関数により、各年の 個体密度を算出する。

・樹木の栄養塩循環への寄与 上記で求められる個 体群に個々の個体の組織別の栄養塩濃度を掛けて、 木本部に貯蔵される年間の栄養塩量の増分を算出 する。次に、上記で求められる個体群の年間の葉 の生産量を算出し、葉に含まれる栄養塩濃度を掛 けて、樹木が吸収した栄養塩のうち、葉に配分さ れた量を算出する。土壌栄養塩量より樹木の個体 群に吸収された量を差し引いて、落葉期以前の土 壤栄養塩濃度を求める。さらに、落葉とともに土 壤表面に堆積する量を算出する。葉の分解速度よ り、各年の土壌への回帰栄養塩量を算出し、土壌 栄養塩量に加える。

\section{（2）草本類のシミュレーション過程}

大型イネ科植物を考慮しない場合

・草本類バイオマス量の算定 土壤窒素濃度より見 積もられるそれぞれの年における年間の草本地上 部のバイオマス量を算出する。土壌粒径によるバ イオマス量の校正を行う。隣接する樹木による影 によるバイオマス量の校正を行う。

- 大型イネ科植物の算定法 大型イネ科植物の侵入 場所を決定する。それぞれの植物群落の年間拡大 速度に従って、群落を拡大させていく。地上部バ イオマスは土壤栄養塩濃度、土壤粒径、樹木によ る陰の影響を考慮して、地上部バイオマス量を算 定する。地上部バイオマス量の $1 / 3$ を地下部バイ オマスとし、その量の $1 / 3$ が毎年枯死していくも のとする。

・栄養塩循環への寄与の算定 上記バイオマス量に 組織別栄養塩濃度を掛けて、土袞中より吸収され た栄養塩量を算出、土袞中の量より差し引く。地 上部が枯死後、分解係数を掛けることによって枯 死後の経過年ごとの土壤中に回帰される栄養塩量 を算出し、土壌栄養塩量に加えて、土壌栄養塩濃 度を算出する。なお、根圈までの深さを対象とす る土壌厚さとする。

\section{（3）土袞窒素濃度}

窒素の大気負荷量に関しては、様々な観測値が入 手可能である。ここでは、こうした值を用いるも のとする。

・冠水後の土㙵栄養塩濃度の設定 水文・水質デー タベース等から、近傍の河川水質の $\mathrm{TN}$ の值を得、 土袞中の $\mathrm{TN}$ 濃度を見積もり、初期值とする。こ れに、大気負荷量、樹木および草本類による栄養 塩収支を加えることにより、土壌栄養塩量の変化 を求める。 


\section{0. モデルの検証}

一部のデータ採取および検証データの採取を兼ね て、2011 年 6-10月に荒川大麻生の砂州において、 土壤・植物についての観測を行った。

砂州の詳細については、Asaeda et al. ${ }^{3,11,13)}$ 、Gomes and Asaeda ${ }^{14)}$ を参照されたい。砂州を斜めに横断す るようなトランゼクトを設定し、その上に16点の測 点を設け、土壌コアサンプル、天空率を測定後、1 測点につき 3 カ所の $50 \mathrm{cmx} 50 \mathrm{~cm}$ のコドラートにおい て、草本類のバイオマスを採取した。土壌サンプル については、土壤水分量、土壤粒径、 $\mathrm{pH} 、 \mathrm{TC} 、 \mathrm{TN}$ 、 $\mathrm{NH}_{4}-\mathrm{N} 、 \mathrm{NO}_{3}-\mathrm{N} 、 \mathrm{TP} 、 \mathrm{PO}_{4}-\mathrm{P}$ が、植物サンプルにつ いては、種同定の後、乾燥重量、TC、TN、TPが測 定された。

Fig. 8 は、それぞれの測点に対する土畩窒素濃度 の、Fig. 9は草本類バイオマスの観測值と計算值を 比較したものである。なお、荒川砂州の他に、 Asaeda et al. ${ }^{15)}$ で報告されている黒部川のデータも同 時に示している。荒川、黒部川共に、十分な精度で 予測がなされている。

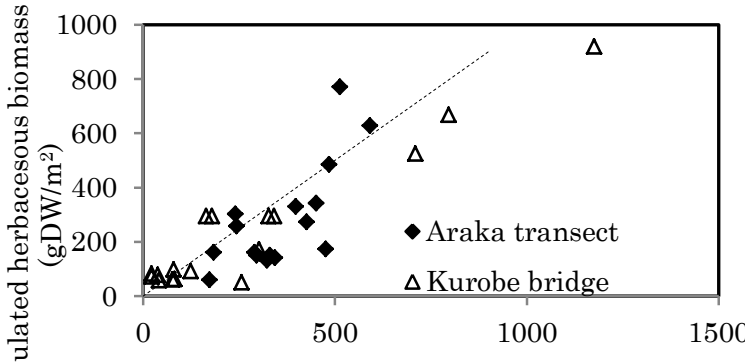

Observed herbaceous biomass $\left(\mathrm{gDW} / \mathrm{m}^{2}\right)$

Fig. 8 The comparison between observed and simulated TN in the soil

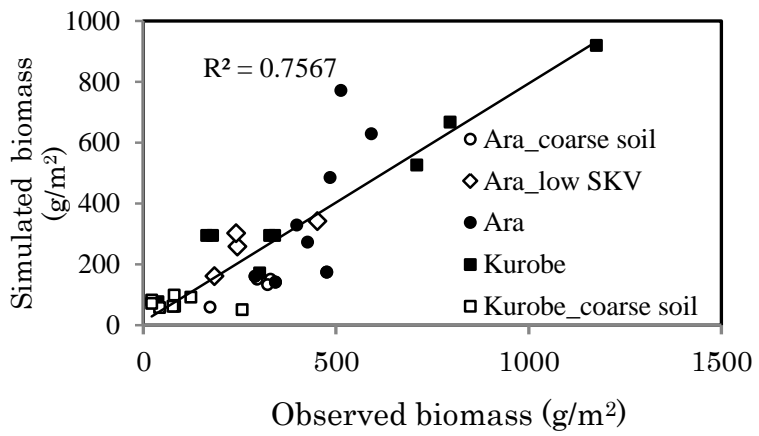

Fig. 9 The comparison between observed and simulated herbaceous plant biomass

以上のモデルを利用して、荒川の砂州上の植生の 遷移について、平面的な再現計算を行った。砂州面 の土壤粒径分布は観測值を用いた(Asaeda et al. ${ }^{3,11,13)}$ )。 計算は、荒川、熊谷の砂州を対象に、1991年の洪 水によってすべての植生が流出後、2007年の洪水前
後の植生の状況について、シミュレーションを行っ た。この間、20回程度の洪水を経験し、その都度、 樹木の流失、定着が生じている。計算は1991年に植 生無しの初期条件から始めている。また、TNの初 期濃度は観測值に基づき $0.13 \mathrm{mg} / \mathrm{g}$ とている。この 関係については今後検討が必要である。

Fig. 10 (a)-(d) は、2007年の洪水直前及び直後の 二セアカシアおよびヤナギの分布の計算結果である。

地形のシミュレーションについては、表層土壤の 洗掘深が湛水深に比例するという簡単な経験式を用 いているので、それぞれの洪水における地形変形を 必ずしも十分に表現できていない。特に、2007 年の 洪水においては、砂州の上流部が大きく流失したも のの、ここではそうしたことは再現できていない。 そのため、砂州の上流部において差異はみられるも のの、ニセアカシアとヤナギの個体分布については、 十分な一致が得られていると考えられる。
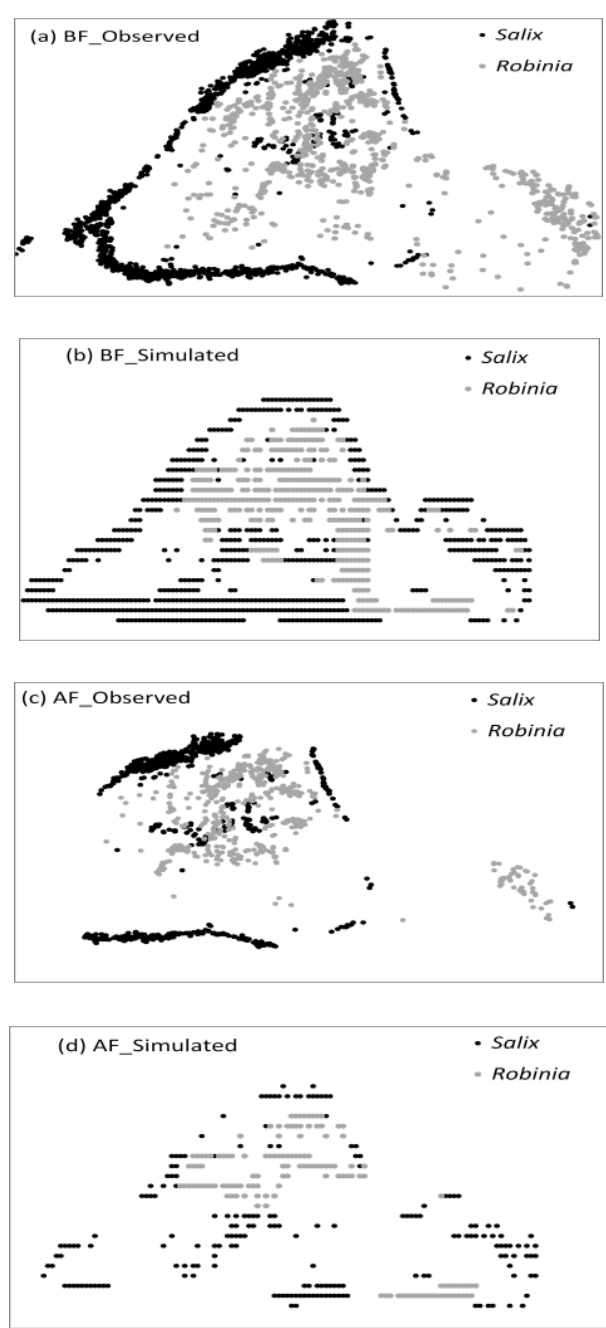

Fig.10 Observed and simulated distribution of individual trees immediately before and after 2007 flood at the sediment bar of Arakawa River 

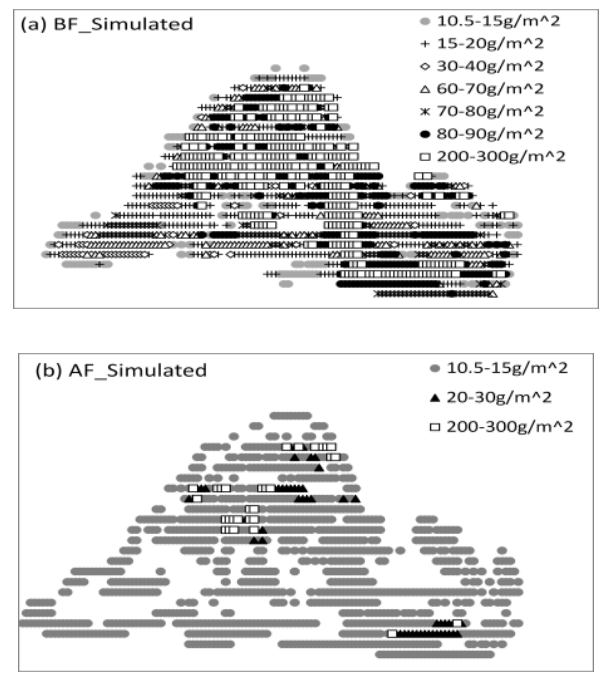

Fig. 11 Simulated results of herbaceous plant biomass before and after the 2007 flood.

洪水による植生流失については、地形変化による影響 が大きいことは既に報告済みであるが(Asaeda et al. ${ }^{3,11)}$ )、 本モデルで樹木の活着も洪水に大きく依存されるこ とが示され、平常時の生長の予測も可能になった。

Fig. 11 は同様に、2007 年の洪水前及び洪水 1 年 後の草本類バイオマスの分布のシミュレーション結 果である。これについては、比較データはないが、 観測の際の写真等の状況から得られた状況がほぼ再 現できている。

\section{1. まとめ}

砂州の土壌は、元来水分量が少なく貧栄養である ため、植物が繁茂することは少ない。近年の植生量 の増加や樹林化の背景には、砂州の土壤の富栄養化、 特に窒素濃度の増加がある。本研究では、これまで 経験的に得られてきた関係を駆使することにより、 砂州土壤の窒素濃度の変化、それによる植生のバイ オマス量を予測するモデルを作成した。一方で、洪 水によって砂州が冠水すると、砂州表面の土䁃が流 失し、同時に植生も失われるため、こうした予測も 必要である。しかし、現在ではこうした過程を予測 する様々な 2 次元河床変動モデルが提案されている 16)。本モデルは、こうしたモデルと連結するために 作成されたもので、そうすることで、実際の河川の 植生の遷移過程も含めた予測が可能になり、より高 度な植生管理に用いることを目指したものである。

本研究を行うにあたり、国土交通省河川技術開発 事業、河川整備基金、文部科学省科学研究費補助金 の援助を受けた。

\section{参考文献}

1) 崎尾 均、山本福壽 : 水辺の生態学. 東京大学出版 会、206, 2002.
2) T.Asaeda, \& L.Rajapakse : Effects of spates of different magnitude on a Phragmites japonica population on a sandbar of a frequently disturbed river. River Research and Applications. Vol.24, pp.1310-1324, 2008.

3) T.Asaeda, P.I.A.Gomes, K.Sakamoto, \& Md.H.Rashid : Tree colonization trends on a sediment bar after a major flood. River Research and Applications, Vol.27, pp.976984, 2011.

4) T.Asaeda, Md.H Rashid, S.Kotagiri, \& T.Uchida : The role of soil characteristics in the succession of two herbaceous lianas in a modified river floodplain. River Research and Applications, Vol.27, pp.591-601, 2011.

5) T.Asaeda, M.B. Baniya, \& Md.H.Rashid : Effects of floods on the growth of Phragmites japonica on the sediment bar of regulated rivers: a modelling approach. International Journal of River Basin Management, Vol.9, pp.211-220, 2011.

6) Steiger J, Tabacchi E, Dufour S, Corenblit D, Peiry JL. : Hydrogeomorphic processes affecting riparian habitat within alluvial channel floodplain river systems: a review for the temperate zone. River Research and Applications, Vol. 21, 719-737, 2005.

7) 蒔田明史、星崎和彦、高田克彦、三嶋賢太郎、田村 浩喜：海岸マツ林に広がるニセアカシア - 秋田県夕 日の松原での研究例より - 、ニセアカシアの生態学、 崎尾 均編、145-159, 2008.

8) 真坂一彦、山田健四：ニセアカシアの種子発芽特性. ニセアカシアの生態学、崎尾 均編、113-130, 2008.

9) 蒔田明史、田村浩喜：「アカシア」香る町 - 小坂鉱山 煙害地における緑化. ニセアカシアの生態学、崎尾 均編、27-41、2008.

10) E.R. Lines, M.A. Zavala, D.W. Purves, \& D. A. Coomes, Predictable changes in aboveground allometry of trees along gradients of temperature, aridity and competition. Global Ecology and Biogeography, Vol.21,pp.1017-1028, 2012.

11) T.Asaeda, P.I.A.Gomes, \& E.Takeda : Spatial and temporal tree colonization in a midstream sediment bar and the mechanism governing tree mortality during a flood event. River Research and Applications, Vol.26, pp.960976, 2010.

12) Zhang D, Hui D, Luo Y, Zhou G.: Rates of litter decomposition in terrestrial ecosystems: global patterns and controlling factors, Journal of Plant Ecology,Vol.1,pp 85-93. 2008

13) T. Asaeda, K. Siong, T. Kawashima, \& K. Sakamoto : Growth of Phragmites japonica on a sandbar of regulated river: Morphological adaptation of the plant to low water and nutrient availability in the substrate. River Research and Applications. Vol.25, pp.874-891, 2009.

14) P.I.A.Gomes, \& T.Asaeda : Spatial and temporal heterogeneity of Eragrostis curvula in the downstream flood meadow of a regulated river. Annales de LimnologieInternational Journal of Limnology, Vol.45, pp.181-193, 2009.

15) T.Asaeda, \& Md.H.Rashid : The impacts of sediment released from dams on downstream sediment bar. vegetation. Journal of Hydrology, Vol.430-431, pp.25-38, 2012.

16) H.Sekine, K.. Sakamoto, T. Nishimura, T., \& T. Asaeda : Development of a simulation model considering vegetation growth and flushing in Arakawa River, KSCE Journal of Civil Engineering, Vol.16, pp.239-246, 2012.

(2013. 9. 30 受付) 